\title{
Contrastive Analysis of Arabic-English Translation of Legal Texts
}

\author{
Omar Osman Jabak \\ Department of Foreign Languages, College of Arts and Sciences, University of Nizwa, Oman
}

\begin{abstract}
The present study aims to provide a contrastive analysis of Arabic-English translation of ten legal texts with an eye to evaluating the accuracy of the translation. The researcher collected the data from ElFarahaty's (2015) Arabic-English-Arabic Legal Translation. A contrastive analysis was developed to assess the accuracy of the translation of the legal texts selected. The examination of the source legal texts and the translations provided either by the authoress of the book herself or the sources from which she collected them revealed serious errors such as overtranslation, omission of translating important words in the source texts, wrong choice of equivalents in the target language, gloss translation, punctuation mistakes in the target texts and grammatical mistakes in the target texts. Further research on the assessment of Arabic-English translation of legal texts is required to encourage professional legal translators and scholars to approach legal translation more professionally and responsibly.
\end{abstract}

Index Terms-Arabic-English translation, faithful translation, legal texts, legal translation

\section{INTRODUCTION}

Employment contracts, official circulars and documents, national and international business contracts, marriage and birth certificates, graduation certificates and even job applications, among other official documents, are examples of legal texts (Cao, 2007; Gotti, 2009; Altarabin, 2018). Legal translation is considered part of technical translation on the grounds that the language used in legal texts tends to be specialized or technical (Malakhova et al, 2015; Cao, 2007; Trosborg, 1997). Legal systems differ from country to country, and so do their legal terminologies (Cao, 2007; Altarabin, 2018). A good legal translator should, therefore, be familiar with the legal systems of the language he/she carries out translation from and the language he/she carries out transition into (Ahmad \& Rogers, 2007; Sarcevic, 1997; Trosborg, 1997; Smith, 1995; Emery, 1989) in order to produce as accurate a translation as possible. Accuracy is the most important element of legal translation (Simms, 1997), and to achieve accuracy, translators have to translate every single word in the source legal text. In translating legal texts, "it is desirable, if not imperative, to have the greatest possible degree of formal correspondence" (Weisflog, 1987, p. 191).

The general field of legal translation is relatively under researched (Juliette, 2020; El-Farahaty, 2015) compared to other fields of translation probably because translation scholars think that the field is subsumed in technical or specialized translation. Moreover, legal texts enjoy a special status in the minds of people and are treated as documents with a legally binding force which is tantamount to the power enjoyed by holy or sacred books (Tiersma, 1999) simply because if the law is broken, legal action will be taken and punishments will ensue. In this respect, the translation of legal texts requires translators to translate every single word in the source text to avoid making any errors if they choose to adopt other approaches to the translation of legal texts. Sarcevic (1997, p. 23) stresses this point by saying "Like the word of God in the Scriptures, the letter of law also demanded strict literal translation to protect it from heterodoxy. Thus, it was believed that the 'word power' of such texts could be retained only by word-for-word translation". The researcher of the current study believes that faithful translation as proposed by Newmark (1998) is the best method for translating legal texts as every word in the source text has an important meaning and merits translating into an equivalent word in the target text. Besides, faithful translation adheres to rendering the meaning of the source text into the target language.

There are a limited number of books on Arabic-English translation and/or English-Arabic translation of legal texts or part of it to the best of the researcher's knowledge and search (e.g., Hassan, 2019; Husni \& Newman, 2015; El-Farahaty, 2015; Lahlali \& Abu Hatab, 2014). However, the choice of El Farahati's book Arabic-English-Arabic Legal Translation was made for some considerations. First, the researcher of the present study was assigned to teach a legal translation course at the Department of Foreign Languages, College of Arts and Sciences at the University of Nizwa in the Fall Semester 2020. He found an electronic copy of the book, downloaded it, read it and then selected some parts for his course as they provided a contrastive approach to Arabic-English translation and English-Arabic translation of legal texts and elaborated on the features of both legal English and legal Arabic. Second, the book maps out the different stages of translation in general and legal translation in particular as well as drawing on previous research on legal translation extensively. This makes the book a very good academic reference on legal translation with regard to ArabicEnglish-Arabic translation of legal texts. Third, while teaching the selected parts of the book to the students, the researcher of the present study noticed some mistakes in either the source texts provided by the authoress of the book, 
the translations produced by the translators/researchers of the source texts or the translations suggested by the authoress herself. Since legal translation requires a high level of accuracy, the researcher decided to conduct a contrastive analysis of a sample of English legal texts along with their English translations with an eye to highlighting serious mistakes in the translation which affect the meaning expressed in the source texts and the accuracy of translation. The researcher of the current study is both an academic and a professional translator with experience in Arabic-English translation and English-Arabic translation of general and specialized texts, including legal texts.

\section{A. The Objectives of the Study}

As there is relatively little research done on the contrastive analysis of Arabic-English translation of legal texts, based on an extensive review of the literature available on this topic, the present study aims to bridge this gap and shed light on a sample of legal texts in Arabic along with their English translations. With this general aim in mind, the present study seeks to achieve the following objectives:

1- To provide a contrastive analysis of the legal texts chosen for this study;

2- To identify errors in the translation of the legal texts under study;

3- To suggest accurate translation for the legal texts chosen for this study.

\section{B. The Statement of the Problem}

The present research study seeks to answer the following two questions:

1- Are the translations of the legal texts under study accurate?

2- What are the errors made in the translation of the legal texts under study?

\section{LITERATURE REVIEW}

The following section will provide a review of the literature available on legal translation in general and ArabicEnglish translation or English-Arabic translation of legal texts along with the various aspects and challenges of translating legal texts in both directions in particular. The researcher selected relatively recent studies on legal translation in an attempt to observe space limitations and provide a review of the most recent literature, although the literature abounds in studies that date back to the 1990s and earlier (e.g., Emery, 1989; Farghal \& Shunnaq, 1992; AlBitar, 1995. The study will also shed light on Newmark's (1998) faithful translation as the most appropriate method for translating legal texts suggested by the researcher of the present study. This also represents the theoretical framework adopted in the present study.

\section{A. Studies on Legal Translation}

To begin with, Loiacono (2013) conducted a study on the strategies for translating legal documents from Australian English into Italian. The researcher of the above study proposed treating cultural legal terms as proper names and adopting the strategies used for translating proper names in the translation of culture-specific legal terms. The researcher mapped out the various approaches to, and strategies for, translating legal documents and strongly advocated the treatment of cultural legal terms as proper names implying the difficulty or impossibility of providing equivalents for such terms in the target language and culture. The scope of the above study and the pair of languages examined are quite different from the scope and pair of languages examined in the present study. The above study focused on one specific aspect of legal texts which is the use of culture-specific legal terms, whereas the present study focuses on testing the accuracy of the English translation of a select number of Arabic legal texts. The above study proposed viewing cultural legal texts as proper names which obviously cannot be translated, whereas the present study proposes adopting faithful translation when translating legal texts.

Hijazi (2013) conducted a study on the evaluation of Arabic translation of English legal texts produced by Google Translate. The researcher selected fourteen English articles from six legal contracts and fed them into Google Translate to assess the quality of the Arabic translation done by Google. The researcher assessed Google's translation of English legal texts in two terms, syntactic and lexical. The study arrived at the general finding that Google Translate produced gist translations of the legal texts which people with legal knowledge could understand. The assessment also showed that the tool could not be used as a useful translation service in the field of legal translation as there were syntactic and lexical errors in the Arabic translations of the English legal texts produced by Google Translate which affected not only the quality but also the accuracy of the translation. The scope and direction of translation of this study are quite different from those of the present study. However, the present study examines human translation of Arabic legal texts into English, while the present study examined the English translation of Arabic legal texts not only in syntactic and lexical terms but also in cultural terms. Finally, the above study used an error analysis to help categorize the errors detected in the translation outputs, whereas the present study employed a contrastive analysis to detect the errors made in the translation outputs.

Al Aqad (2014) conducted a study on Arabic-English translation of five marriage contracts to identify linguistic and cultural equivalence with regard to Arabic and English legal systems. The researcher adopted a pragmatic approach to comparing the meaning expressed in the source texts to the meaning conveyed in the target texts. The results obtained from that comparison led him to the conclusion that literal translation of some culture-specific terms and phrases in the 
Arabic marriage contracts resulted in vague, incorrect meaning. Based on that finding, the researcher suggested using functional and communicative approaches to Arabic-English translation of marriage contracts. This study and the present study both examine legal translation from Arabic into English. Although the above study used Newmark's (1998) classification of translation methods and Baker's (1992-2006) levels of equivalence, the researcher did not explicitly adopt any specific method for his study, whereas the current study clearly showed that Newmark's faithful translation was the most appropriate method for translating legal texts. In addition, the general finding of the above study that literal translation cannot be followed in legal translation is in line with one of the findings of the present study that literal translation cannot be always followed when translating legal texts from Arabic into English.

Gotti (2016) carried out an exploratory study on the translation of legal texts from intralinguistic and interlinguistic perspectives. The researcher analyzed some legal texts and their translations and came to the conclusion that "the translation of legal texts is a very complex procedure, greatly conditioned by specific factors strictly depending on the different cultural, linguistic and legal environments in which it takes place." (p. 19). The present study agrees with the researcher of the above study that translation of legal texts is not a simple or easy task. The researcher of the above study also argued that translation of legal texts "may be influenced by different target users with their own legal culture and drafting traditions." (ibid). As this finding suggests, the scope of this study is quite different from the scope of the present study, and so are the languages compared and contrasted with regard to legal translation. Yet, the above study shed some light on very important issues of legal translation in terms of source languages, target languages, drafting traditions, target users and strategies adopted in legal translation in general.

Alrikabi (2017) carried out a study on the translation of twelve contracts from Arabic into English with any eye to identifying the errors made by professional translators in the English translation of the Arabic contracts. The study arrived at important findings on the English translation of the Arabic contracts at the linguistic, stylistic and cultural levels. The errors made in these fields made the translation both ambiguous and incorrect. One striking resemblance between the above study and the present study lies in the direction of legal translation which is Arabic into English. The scope of the present study is different from that of the above-mentioned study in terms of the types of legal texts used as the sample of the study. The above study used one type of legal texts represented in twelve English contracts, whereas the present study used different types of Arabic legal texts such as contracts, official documents, official speeches and the sorts. However, the types of errors identified in both the present study and this study are, for the most part, similar, despite the difference in the direction of translation.

Altarabin (2018) conducted a study on the challenges of translating English legal documents into Arabic. His study is a general investigation into the difficulties which legal translation poses to translators. He argued that the difficulties "include, but are not limited to, lexical features, connotative meaning, contextual meaning, intra-system difference, translators' [lack of] familiarity with legal terminology and lack of uniformity between legal documents in different legal systems." (p. 208). The findings of the present study with regard to errors in legal translation could be attributed to some of the difficulties proposed in the above study. The scope and pair of languages examined are, to some extent, similar in both the above study and the present study. However, the above study did not use any theoretical framework nor did it suggest any method for legal translation, unlike the present study which adopts faithful translation proposed by Newmark (1998) as both its theoretical framework and the most appropriate method for translating Arabic legal documents into English.

\section{B. Newmark's Translation Methods}

Newmark (1998, pp. 45-47) proposed eight translation methods which are word -for-word translation, literal translation, faithful translation, semantic translation, adaptation, free translation, idiomatic translation and communicative translation. The researcher thinks that 'faithful translation' is the most appropriate method for translating legal texts as "A faithful translation attempts to reproduce the precise contextual meaning of the original within the constraints of the TL grammatical structures" (Newmark, 1998, p. 46). This means that a faithful translation of any given legal text seeks to preserve the meaning of the source text which also entails preserving the meaning of every single word of the source text. In Newmark's own words, a faithful translation "attempts to be completely faithful to the intentions and the text-realisation of the SL write." (ibid). The researcher of the present study also thinks that the adoption of faithful translation for translating Arabic legal texts into English will achieve what has been referred to as "legal equivalence” (Beaupre', 1986, p. 179).

\section{METHODOLOGY}

\section{A. Data Collection and Procedure}

The researcher collected the data for the present study from El-Farahaty's (2015) Arabic-English-Arabic Legal Translation. In fact, ten Arabic legal texts, which varied in length and topics, along with their English translations were selected as the data to be examined and analyzed. Although the book examined Arabic-English translation and EnglishArabic translation of legal texts, the researcher confined his study to the Arabic-English translation of legal texts in order to narrow the scope of his investigation. It should be mentioned that the authoress of the above-mentioned book took the legal texts from a variety of sources primarily concerned with legal translation (e.g Hatim et al, 1995; Mansoor, 1996b) and provided the English translations for those texts either from the same sources, and when there were no 
translations, she proposed her own translations. To help analyze the source texts and the target texts in a visual manner, the researcher developed a contrastive analysis table.

\section{B. Data Analysis}

After selecting the Arabic texts with their English translations, the researcher devised ten contrastive analysis tables each of which included three columns; one for the source text, one for the target text and one for his own translation based on Newmark's (1998) faithful translation so that the reader will easily and readily spot the inaccuracies of the target texts. It is worth mentioning that the researcher drew on his long experience in translation to provide his own translations for the source texts and use them as model translations against which the target texts could be measured. The contrastive analysis conducted revealed serious lexical errors in the target texts which cannot simply be ignored as they, not affected the quality of translation, but they also provided different meanings for the target texts which made the translations unfaithful.

\section{RESULTS AND DISCUSSION}

After collecting the data from El-Farahaty's (2015) Arabic-English-Arabic Legal Translation, the researcher examined the source texts and the target texts. It is worth mentioning here that the target texts were either translated by the authoress herself, El-Farahaty, or the authoress took them from other sources. The researcher examined both types of texts in terms of faithful translation as proposed by Newmark (1998). To help identify the translation errors spotted in the target texts, the researcher developed contrastive analysis tables in which he listed the source texts, the target texts and his own faithful translation. By looking at the tables, it is hoped that readers will have a general idea about the findings of the study which will be explained in detail in the subsequent paragraphs.

As Table 1 below shows, the first source text includes an Arabic word "wِيادة" whose English equivalent is "sovereignty". However, the translator did not translate the Arabic word into English, although the word is very important and has a common equivalent in English. The authoress of the book should have identified this as a translation error and drawn attention to it as the text is legal and the word, which was not translated, is very important in legal and political contexts. Table 1 below provides the first source text, the target text and the faithful translation of the source text proposed by the researcher.

TABLE 1

SOURCE TEXT 1, TARGET TEXT 1 AND FAITHFUL TRANSLATION

\begin{tabular}{|c|c|c|}
\hline Source text 1 & $\begin{array}{r}\text { Target text } 1 \\
\end{array}$ & Researcher's faithful translation \\
\hline 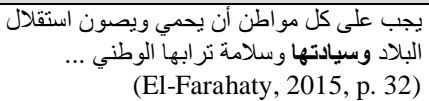 & $\begin{array}{l}\text { The duty of every citizen is to protect and } \\
\text { safeguard the independence of the country and } \\
\text { the integrity of its national territory. (ibid) }\end{array}$ & $\begin{array}{l}\text { Every citizen must protect and safeguard the } \\
\text { independence and sovereignty of the country and } \\
\text { its national territory. }\end{array}$ \\
\hline
\end{tabular}

In the second target text, there are two translation errors; one a wrong choice of word and the other an overtranslation which both result in an unfaithful translation. As for the first error, the translator translated the Arabic word "الرّّن into English as "apostles" which does not cover the lexical and intended meaning of the Arabic religious word. The word should have been translated into English as "messengers". The other translation error spotted in this text is the addition of a word in the target text which has no Arabic equivalent in the source text at all. In other words, the translator overtransated and added a translation of a word that does not exist in the source text. This is really dangerous and unacceptable at all. However, the authoress of the book did not comment on this grave error! She should have criticized the decision made by the translator to add a translation of a word that does not exist in the source text. But, she did not say anything about that. The Arabic phrase "وتجفيف منابعها الفكرية" was translated into English as "and drying out of its cultural and intellectual wells". The addition of "cultural" which has no equivalent in the Arabic source phrase is not justifiable at all. Table 2 below provides the second source text, the target text and the researcher's faithful translation.

TABLE 2

SOURCE TEXT 2, TARGET TEXT 2 AND FAITHFUL TRANSLATION

\begin{tabular}{|c|c|c|}
\hline Sou & Targ & Researcher's faithful tı \\
\hline 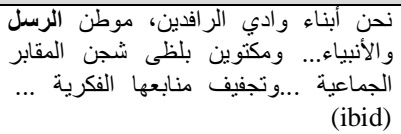 & $\begin{array}{l}\text { We, the people of Mesopotamia, the homeland of } \\
\text { apostles and prophets ... and burnt by the flames of } \\
\text { grief of the mass graves . . . and drying out of its } \\
\text { cultural and intellectual wells. (ibid) }\end{array}$ & $\begin{array}{l}\text { We, the people of Mesopotamia, the homeland of } \\
\text { messengers and prophets } \ldots \text { and burnt by the } \\
\text { flames of the mass graves ... and drying out of its } \\
\text { intellectual wells. }\end{array}$ \\
\hline
\end{tabular}

Those who know Arabic and English can easily see that the translator added the English adjective "cultural" which means in Arabic "ثقافية" that does not exist in the Arabic phrase! A miss is good as a mile, and overtranslation is an error especially in the translation of sensitive texts such as legal or political texts.

In the third target text, there are two errors of overtranslation. The source text is simple and short. Yet, the translator added two translation items one of which changed the meaning of the source text, and the other one was apparently redundant and tautologous. In the source text, there is the verb "تُضضي" whose English equivalent is just "result in", and not "may result in". The addition of "may" to the target text verb "result in" changes the meaning expressed and intended in the source text verb "تُفضي" from a fact into a possibility. In legal translation, translators have to be faithful 
to the source text and its meaning; any addition, deletion or modification not only changes meaning but can also cause disputes, some of which might be both serious and hard to settle. The other error of overtranslation is the addition of the adjective "genocidal" which does not have any counterpart in the source text. The word "فإ:" in the source text is equivalent to "annihilation" in English. However, the translator added the adjective "genocidal" before "annihilation" unnecessarily and redundantly. The authoress should have identified these errors and commented on them in her book as her book deals with legal translation which should be accurate and faithful. Table 3 below provides the third source text, the target text and the researcher's faithful translation.

TABLE 3

SOURCE TEXT 3, TARgET TEXT 3 AND FAithFul TRANSLATION

\begin{tabular}{|c|c|c|}
\hline $\begin{array}{c}\text { Source text } 3 \\
\end{array}$ & Target text 3 & Researcher's faithful translation \\
\hline $\begin{array}{r}\text { الينبوع اللشري. إلى وسائل تفضي إلى إفناء } \\
\text { (El-Farahaty, 2015,p. 33) }\end{array}$ & $\begin{array}{l}\text { It is forbidden to resort to such means as may } \\
\text { result in the genocidal annihilation of mankind. } \\
\text { (ibid) }\end{array}$ & $\begin{array}{l}\text { It is forbidden to resort to means that result in the } \\
\text { annihilation of mankind. }\end{array}$ \\
\hline
\end{tabular}

In the fourth target text produced by the authoress herself, there are several serious errors which render the target text

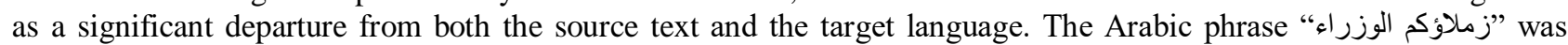
wrongly translated into "colleague ministers" which sounds strange in English since "colleague" and "ministers" are both nouns. The faithful translation for the Arabic phrase is "fellow ministers" as "fellow" is an adjective here modifying the noun "ministers". The phrase " وما تقليدكم المسؤولية إلا عربون تقدير" was also translated wrongly into English as "It is nothing but an appreciation". The authoress used gloss translation to render that phrase, but she changed both the meaning and structure of the target phrase. The faithful translation for the above Arabic phrase is "Giving you this responsibility is but a token of appreciation". The Arabic phrase " was also translated wrongly by the authoress as she could not choose an appropriate equivalent for the Arabic adjective "محنّ" which she mistakenly translated as "wise", and "wise" is the equivalent of "حكيم" in Arabic, not "محنّك" Following faithful translation, the researcher suggested the English adjective "resourceful" as an equivalent for the Arabic adjective "sliّ" The Arabic phrase "كفاء|تكم" was translated wrongly into "your skills" instead of "your competence" as the English equivalent for

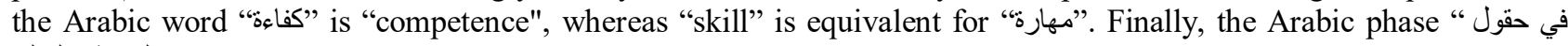
" التربية والتعليم "was translated into English by the authoress of the book wrongly as "in the field of teaching and learning”. The faithful translation for this phrase is "in the fields of education and teaching" as education and teaching are two interrelated fields whose Arabic equivalents are "التربية والتعليم", while the proposed terms "teaching and learning" are equivalents for two completely different words in Arabic which are "التربية "التعليم والتعلّم". The best method of legal translation which accounts for accuracy is faithful translation, but it seems that the authoress ignored this method when she proposed her translation, although the book is about legal translation! Table 4 below provides the fourth source text, the target text and the researcher's faithful translation.

TABLE 4

SOURCE TEXT 4, TARGET TEXT 4 AND FAITHFUl TRANSLATION

\begin{tabular}{|c|c|c|}
\hline Source text 4 & Target text 4 & Researcher's faithful translation \\
\hline 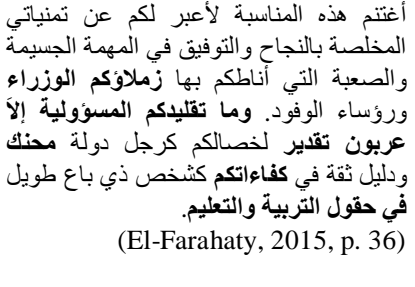 & $\begin{array}{l}\text { I seize this opportunity to wish you every success } \\
\text { in accomplishing the challenging and difficult task } \\
\text { which has been entrusted to you by your colleague } \\
\text { ministers and the heads of delegations. It is } \\
\text { nothing but an appreciation of your qualities as a } \\
\text { wise statesman and confidence in your skills and } \\
\text { long experience in the field of teaching and } \\
\text { learning. } \\
\text { (Author's translation) (ibid) }\end{array}$ & $\begin{array}{l}\text { I seize this opportunity to express my sincere } \\
\text { wishes for your success and luck in the great and } \\
\text { hard task which your fellow ministers and heads } \\
\text { of delegations have entrusted you with. Giving } \\
\text { you this responsibility is but a token of } \\
\text { appreciation of your qualities as a resourceful } \\
\text { statesman and proof of confidence in your } \\
\text { competence as a person with long experience in } \\
\text { the fields of education and teaching. }\end{array}$ \\
\hline
\end{tabular}

In the fifth target text as Table 5 below shows, there are three errors made by the authoress of the book. The first one is the mistranslation of the Arabic phrase "الأخ العقيد مُعمّر القذّافي”. The authoress did not translate it faithfully by adhering to the word order of the source text which is important here. The faithful translation of this phrase is "Brother and Colonel Mu'ammar al-Qadhafy" and not "Brother and leader, Colonel Mu'ammar al-Qadhafy". The other error is the misunderstanding of the noun which the Arabic adjective "عظيم" refers to. The authoress mistakenly thought that the

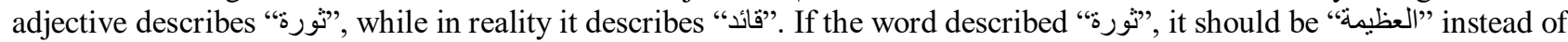
"العظيم". The last error which is also very serious is the mistranslation of the famous revolution in the modern history of Libya known as "ثورة الفاتح" whose English equivalent is the September Revolution or Al-Fatih Revolution. Unfortunately, the authoress translated that culture-specific phrase literally which distorted the cultural dimension of the phrase. Table 5 below provides the fifth source text, the target text and the researcher's faithful translation. 
TABLE 5

SOURCE TEXT 5, TARgET TEXT 5 AND FAITHFUl TRANSLATION

\begin{tabular}{|c|c|c|}
\hline Source text 5 & Target text 5 & Researcher's faithful translation \\
\hline 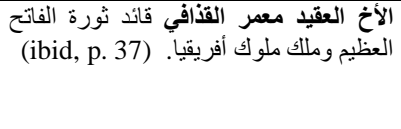 & $\begin{array}{l}\text { Brother and leader, Colonel Mu'ammar al- } \\
\text { Qadhafy, guide of the great victorious revolution } \\
\text { and king of kings of Africa. } \\
\text { (Author's translation) (ibid) }\end{array}$ & $\begin{array}{l}\text { Brother and Colonel Mu ammar al-Qadhafy, } \\
\text { great leader of the September Revolution/ Al- } \\
\text { Fatih Revolution and king of African kings. }\end{array}$ \\
\hline
\end{tabular}

The target text of the sixth legal text, as Table 6 below shows, contains two obvious errors which should not have escaped the attention of the authoress of the book. The first error is the mistranslation of the Arabic word "سكرنير" which is an example of loan translation as it is originally taken from Latin through either English or French. Unfortunately, the translator provided a wrong equivalent for it which is "Assistant", and this word is an equivalent for another Arabic word which is "مُساعِد". The equivalent for "سكرنير" in English is "secretary". The other error is the

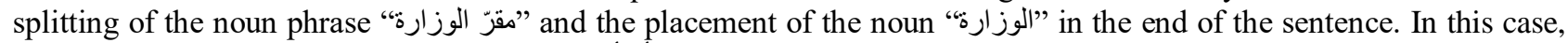
the correct translation of the phrase "في مقرّ الوزارة أو أحد فروعها" is "in the headquarters of the Ministry or its branches", and not "in the headquarters or the branches of the Ministry". Table 6 below presents the sixth source text, the target text and the researcher's faithful translation.

TABLE 6

SOURCE TEXT 6 , TARGET TEXT 6 AND FAITHFUL TRANSLATION

\begin{tabular}{|c|c|c|}
\hline Source text 6 & Target text 6 & Researcher's faithful translation \\
\hline 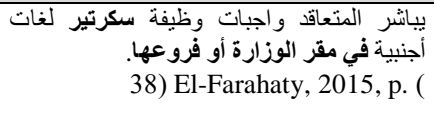 & $\begin{array}{l}\text { The contracted party shall carry out the duties of } \\
\text { Foreign Languages Assistant in the } \\
\text { headquarters or the branches of the Ministry. } \\
\text { (ibid) }\end{array}$ & $\begin{array}{l}\text { The contracted party shall carry out the duties of } \\
\text { the Foreign Languages Secretary in the } \\
\text { headquarters of the Ministry or its branches. }\end{array}$ \\
\hline
\end{tabular}

The target text of the seventh source text which was produced by the authoress of the book contains three mistakes in translation. The first one has to do with the use of "shall" in legal contracts instead of simple present. In fact, the authoress mentioned this rule in her book, but she forgot to follow it when offering her own translation of a legal text. So, the Arabic expression "يُقسخ هذا العقد" should have been translated into English as "This contract shall be revoked" instead of "This contract is revoked". The other mistake is in the mistranslation of the Arabic word "تُّائياً " which simply means "automatically" in English. However, the authoress translated it into English as "absolutely" which is equivalent

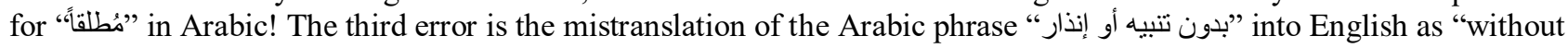
any prior notice", although the English faithful translation of this short and simple phrase is "without any notice or warning". It should be noted here that the authoress' translation "without any prior notice" is equivalent to the Arabic phrase “بدون أبي سابق تنبيه"! Table 7 below provides the seventh source text, the target text translated by the authoress of the book and the researcher's faithful translation.

TABLE 7

SOURCE TEXT 7, TARGET TEXT 7 AND FAITHFUL TRANSLATION

\begin{tabular}{|c|c|c|}
\hline Source text 7 & Target text 7 & Researcher's faithful translation \\
\hline $\begin{array}{l}\text { إنذفار في هذا العقد فورأ وتلقائياً وبدون تنبيه أو } \\
\text { (El-Farahaty, 2015, p. 41) }\end{array}$ & $\begin{array}{l}\text { This contract is revoked immediately and } \\
\text { absolutely without any prior notice if. } \\
\text { (Author's translation) (ibid) }\end{array}$ & $\begin{array}{l}\text { This contract shall be revoked immediately and } \\
\text { automatically without any notice or warning } \\
\text { if ... }\end{array}$ \\
\hline
\end{tabular}

As for the target text of the eighth legal text, it was also produced by the authoress of the book. The examination of the target text with reference to faithful translation revealed serious errors made by the authoress. The first one is the mistranslation of the Arabic word "פقِق" which has a common legal equivalent in English that is "jurisprudence". The authoress translated it into English as "law" which is equivalent for "القانون" in Arabic. The other issue is the rendition of the Arabic phrase "نون "into English as "the type of crime committed and which is therefore punishable". As can be seen from the source phrase and the English translation provided by the authoress, the English المرتكبة ، المعاقب عليها" is simply "punishable" without the use of the relative clause. In fact, the words " و المعاقب عليها "both act as adjectives for the noun " in Arabic, and surprisingly enough their English equivalents "committed and punishable" also act adjectives for the noun "crime". One wonders why the authoress did not provide those equivalents which could have retained a kind of lexical balance in the target text. The next error is that of omission followed by an error in punctuation in a short sentence. The Arabic sentence is “ فإذا كانت الجريمة يعاقب عليها القانون بالإعدام أو الأشغال الثشاقة أو السجن فهي جناية "which was translated into English as "If the crime is to be punished by death or hard labour or imprisonment, it is a felony”. The Arabic legal expression "يعاقب عليها القانون" has an English legal equivalent which is "is punishable by law", and not as the authoress suggested "is punished by law". The other issue in the above translation of the Arabic sentence above-mentioned is the repetition of the conjunction "or" twice just as in the Arabic phrase "بالإعدام أو الأشغال الثاقة أو السجن" which is wrong in English. Instead, a comma is used join the first and the second noun, and the conjunction "or" is used to join the second noun with the third noun. Such mistakes give the impression that the translator is inexperienced, to say the least. Table 8 below provides the eighth source text, the target text translated by the authoress of the book and the researcher's faithful translation. 
TABLE 8

SOURCE TEXT 8, TARGET TEXT 8 AND FAITHFUL TRANSLATION

\begin{tabular}{|c|c|c|}
\hline Source text 8 & Target text 8 & Researcher's faithful translation \\
\hline 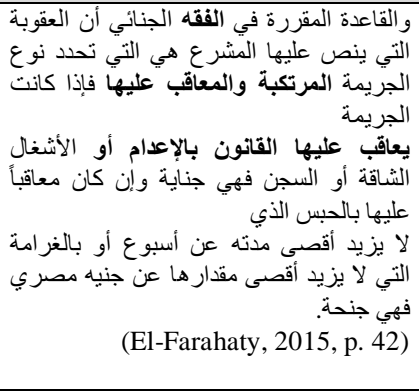 & $\begin{array}{l}\text { The rule established in criminal law is that the } \\
\text { punishment which is prescribed by the legislator } \\
\text { determines the type of crime committed and } \\
\text { which is therefore punishable. If the crime is to } \\
\text { be punished by death or hard labour or } \\
\text { imprisonment, it is a felony. If the crime is to be } \\
\text { punished by imprisonment the maximum duration } \\
\text { of which does not exceed a } \\
\text { week or a fine the maximum amount of which does } \\
\text { not exceed one Egyptian pound, it is a } \\
\text { misdemeanour. } \\
\text { (Author's translation) (ibid) }\end{array}$ & $\begin{array}{l}\text { The rule established in criminal jurisprudence is } \\
\text { that the punishment prescribed by the legislator } \\
\text { determines the kind of crime committed and } \\
\text { punishable. If the crime is punishable by law by } \\
\text { death, hard labor or prison, it is a felony, but if it } \\
\text { is punishable by imprisonment whose maximum } \\
\text { period does not exceed one week or by a fine } \\
\text { whose maximum amount does not exceed one } \\
\text { Egyptian pound, it is a misdemeanor. }\end{array}$ \\
\hline
\end{tabular}

As for the target text of the ninth legal text, it was also produced by the authoress of the book. A close examination of the target text with reference to faithful translation revealed serious errors made by the authoress. The first error, as Table 9 shows, lies in the translation of the Arabic expression "راغبو الهجرة الدائمة" which was rendered by the authoress as "wishing permanent emigration". When following faithful translation, the target language rules should also be taken into account. With reference to the above Arabic expression, the suggested translation based on faithful translation is "wishing to emigrate permanently" which obeys the rules of English with regard to what comes after the verb "wish".

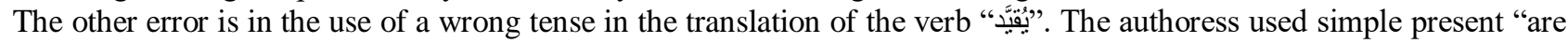
to be recorded", while the tense should be simple future with the use of "shall" in legal texts "shall be enrolled". Besides, the Arabic verb "يُقِّ" whose English equivalent is "enroll" in this context was mistranslated into English as "record" by the authoress. The Arabic phrase " الوزارة المختصة بشئون الهجرة" was mistranslated into "the Ministry of Emigration" which is equivalent to "وزارة الهجرة" in Arabic. The authoress chose to delete the translation of "شئون" " which is an important word in this legal context. Based on faithful translation, the English translation for the above Arabic phrase is "the Ministry of Emigration Affairs". Another error in the target text which is related to punctuation is the unnecessary use of parenetical commas with the phrase "at their request". One more mistake made in the target text is the use of simple present in the translation of the verb "تُوز " instead of simple future with the use of "shall" in legal texts. The authoress translated that verb into English as "are to be distributed" whereas the correct one based on faithful translation should be "shall be distributed". In addition, the preposition following the verb "distribute" is not "on" as the authoress used which is a literal translation of the Arabic preposition "على". The preposition following "distribute" in English is either "to" or "among". Another error is the mistranslation of "إمكانياتهم" into English as "abilities", while its correct equivalent is "capabilities". The last error in this table is the mistranslation of the Arabic phrase " الاحتياجات" "المطلوبة" into English as "the requirements", while the correct equivalent is "the needs required" based on faithful translation which should be adopted when translating legal texts. Table 9 below provides the ninth source text, the target text translated by the authoress of the book and the researcher's faithful translation.

TABLE 9

SOURCE TEXT 9, TARGET TEXT 9 AND FAITHFUL TRANSLATION

\begin{tabular}{|c|c|c|}
\hline Source text 9 & Target text 9 & Researcher's faithful translation \\
\hline 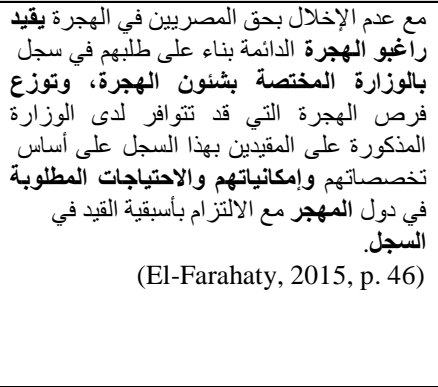 & $\begin{array}{l}\text { Without prejudice to the right of the Egyptians to } \\
\text { emigration, names of those wishing permanent } \\
\text { emigration are to be recorded, at their request, } \\
\text { with the Ministry of Emigration. With a } \\
\text { commitment to the primacy enrolment in a } \\
\text { register, emigration opportunities that may be } \\
\text { available to the said Ministry are to be } \\
\text { distributed on those enrolled in the register on } \\
\text { the basis of their specialization and their abilities } \\
\text { and the requirements of the countries they will } \\
\text { emigrate to. } \\
\text { (Author's translation) (ibid) }\end{array}$ & $\begin{array}{l}\text { Without prejudice to the right of the Egyptians to } \\
\text { emigration, names of those wishing to emigrate } \\
\text { permanently shall be enrolled at their request at } \\
\text { the registry of the Ministry of Emigration } \\
\text { Affairs. Emigration opportunities which may be } \\
\text { available to the said ministry shall be distributed } \\
\text { to those enrolled at the registry based on their } \\
\text { specializations, capabilities and the needs } \\
\text { required in the countries to which they shall } \\
\text { emigrate with a commitment to the primacy } \\
\text { enrolment in the registry. }\end{array}$ \\
\hline
\end{tabular}

The English translation of the tenth and last legal text which was also produced by the authoress of the book contained serious issues. A close examination of the target text with reference to faithful translation revealed serious errors made by the authoress. The first error is the mistranslation of the Arabic phrase " المبادلات التجارية" into English as "trade exchange" although the equivalent phrase, based on faithful translation, is "commercial exchanges". The authoress used a singular noun for the Arabic plural noun "المبادلات". The second issue is related to the translation of the Arabic phrase " لكل من رعايا الدولتين". The authoress chose "the nationals of each state" which can be translated back into

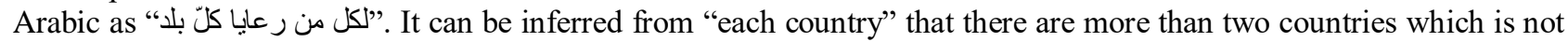
true. The authoress could have simply used "both countries" as an equivalent for the Arabic phrase "الدولنين". The other issue with the authoress' English translation "the nationals of each state" is the use of "state" to mean a country, although "state" is a political term which can also mean a large part of a country. It would be better and clearer if the authoress used the common word "country" to avoid any kind of lexical ambiguity in this legal context. The other error 
in the choice of words is the mistranslation of the Arabic phrase " is " in تسهيل" Ento Elish as "all facilities", while the correct equivalent for "تصهيل" in English is "facilitation", and not "facilities" which means buildings where some activities take place. The other error is the wrong choice of an English word for the Arabic word "مو" "مو" The authoress chose "subject to" which does not express the meaning of the Arabic word "مو افق". Based on faithful translation which should be followed and observed in legal translation, the English equivalent for this Arabic word is simply "in line with", and not "subject to". The last error is the unnecessary use of the comma before "subject to". Table 10 below provides the tenth source text, the target text translated by the authoress of the book and the researcher's faithful translation.

TABLE 10

SOURCE TEXT 10, TARGET TEXT 10 AND FAITHFUL TRANSLATION

\begin{tabular}{|c|c|c|}
\hline Source text 10 & Target text 10 & Researcher's faithful translation \\
\hline 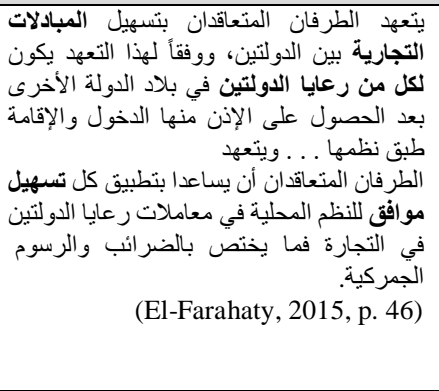 & $\begin{array}{l}\text { The two Contracting Parties undertake to } \\
\text { facilitate trade exchange between the two } \\
\text { countries. According to this pledge, the nationals } \\
\text { of each state reside in the territory of the other } \\
\text { state after obtaining the permission of entry and } \\
\text { residence according to its regulations } \\
\ldots \text {. The two Contracting Parties pledge to help } \\
\text { implement all facilities, subject to their local } \\
\text { systems, in the treatment of the nationals of the } \\
\text { two countries in trade, with regards to taxes and } \\
\text { customs duties. } \\
\text { (Author's translation) (ibid) }\end{array}$ & $\begin{array}{l}\text { The two Contracting Parties pledge to facilitate } \\
\text { commercial exchanges between both countries. } \\
\text { According to this pledge, the nationals of both } \\
\text { countries in the other country, after having got } \\
\text { permission, shall enter and reside in it as per its } \\
\text { rules and regulations ... The two Contracting } \\
\text { Parties pledge to help implement all kinds of } \\
\text { facilitation in line with the local rules and } \\
\text { regulations in the dealing of the nationals of both } \\
\text { countries in trade with regard to taxation and } \\
\text { customs duties. }\end{array}$ \\
\hline
\end{tabular}

\section{CONCLUSION}

The present study has provided a contrastive analysis of ten legal texts in Arabic along with their English translations which have been collected from El-Farahaty's (2015) Arabic-English-Arabic Legal Translation. The researcher has meticulously examined the English translations in terms of accuracy and errors by applying Newmark's (1998) method of faithful translation and found that the English translations exhibited serious errors which affected both the meaning expressed in the target language and the quality of translation. The errors spotted in the English translations produced either by the authors of the sources quoted in the above-mentioned book or by El-Farahaty, the authoress of the book, included overtranslation, omission of translating important words in the source texts, wrong choice of words or equivalents in the target language, gloss translation, misunderstanding of part of the source text, literal translation, punctuation mistakes in the target texts and finally grammatical mistakes in the target texts. Such errors mean that the authoress did not examine the translations carefully while writing the manuscript of the book, or most likely she did not give the manuscript to experts in Arabic-English legal translation who might have discovered the errors and corrected them. Another possible reason is that the authoress lacks practical experience in translation.

Based on the findings of the study, the researcher recommends that further research on the assessment of ArabicEnglish translation of legal texts is required in order to encourage professional legal translators and scholars in the field of legal translation to approach legal translation more professionally and responsibly. Towards that end, either quantitative or qualitative studies can be conducted so that more attention is paid to this important kind of translation.

\section{REFERENCES}

[1] Abu-Ghazal, J. (1996). Major problems in legal translation. (Unpublished M.A. thesis). Yarmouk University. Irbid. Jordan.

[2] Ahmad, K. \& Rogers, M. (Eds.) (2007). Evidence-based LSP: Translation, Text and Terminology. Peter Lang.

[3] Al Aqad, M. H. (2014). Translation of Legal Texts between Arabic and English: The Case Study of Marriage Contracts. AWEJ, 5(2), 110-121.

[4] Al-Bitar, T. (1995). Some syntactic and lexical characteristics of legal agreements and contracts written in English. (Unpublished M.A. thesis). University of Jordan. Amman. Jordan.

[5] Altarabin, M. (2018). Translating English Legal Lexical Features into Arabic: Challenges and Possibilities. AWEJ, 2(2), 199209.

[6] Baker, M. (1992). In Other Words: A course book on translation. London: Routledge.

[7] Beaupre', M. (1986). Interpreting Bilingual Legislation. Carswell.

[8] Cao, D. (2007). Translating Law. Multilingual Matters.

[9] El-Farahaty, H. (2015). Arabic-English-Arabic Legal Translation. Routledge. London.

[10] Emery, P.G. (1989). Legal Arabic Text: Implications for Translation. Babel, 35, 35-40.

[11] Farghal M. and Shunnaq A., (1992). Major problems in students' translations of English legal texts into Arabic. Babel, 38(4), 203-209.

[12] Gotti, M. (2016). The Translation of Legal Texts: Interlinguistic and Intralinguistic Perspectives. ESP Today, 1(4), 5-21.

[13] Gotti, M. (2009). "Globalization Trends in Legal Discourse", in Francis Olsen, Alexander Lorz and Dieter Stein (eds.). Translation Issues in Language and Law. Palgrave Macmillan, 55-75.

[14] Hatim, B., Shunnaq, A. and Buckley, R. (1995) The Legal Translator at Work: A Practical Guide, Jordan: Irbid: Dar Al-Hilal for Translating and Publishing. 
[15] Hassan, B. (Ed). (2019). Working with Different Text Types in English and Arabic: Translation in Practice. Cambridge Scholars Publishing.

[16] Hijazi, B. A. (2013). Assessment of Google's Translation of Legal Texts (Unpublished MA dissertation). University of Petra. Jordan.

[17] Husni, R., and Newman, D. L. (2015). Arabic-English-Arabic Translation: Issues and Strategies. Routledge.

[18] Lahlali, E., and Abu Hatab, W. (2014). Advanced English-Arabic Translation: A practical Guide. Edinburgh University Press.

[19] Loiacono, R., Cesare. (2013). Legal terms as proper names: The translation of culturally specific legal terms in bilateral agreements between Australia and Italy (Unpublished doctoral thesis). University of Western Australia. Australia.

[20] Malakhova A, et al. (2015). Difficulties of Legal Translation. In Young Scientist USA, Vol. 2 (p. 139). Lulu Press.

[21] Mansoor, M. (1965a). Legal and Documentary Arabic Reader (vol. 1), E. J. Brill.

[22] Newmark, P. (1998). A textbook of translation. Longman.

[23] Sarcevic, Susan. (1997). New Approach to Legal Translation, Kluwer Law International.

[24] Simms, K. (1997). Introduction. In K. Simms (Ed.), Translating sensitive texts. Linguistic aspects (pp. 1-26). Rodopi.

[25] Smith, S. A. (1995). Cultural Clash: Anglo-American Case Law and German Civil Law in Translation. In Marshall Morris (Ed.), Translation and the Law (pp. 179-200). John Benjamins.

[26] Scott, Juliette. (2020). An Online Survey as a Means to Research the 'Outstitutional' Legal Translation Market. In Łucja Biel, Jan Engberg, Vilelmini Sosoni and Rosario Marino Ruano (Eds.), Research Methods in Legal Translation and Interpreting Crossing Methodological Boundaries (pp. 166 - 187). Routledge.

[27] Tiersma, Peter M. (1999). Legal Language. University of Chicago Press.

[28] Trosborg, A. (1997). Rhetorical Strategies in Legal Language: Discourse Analysis of Statutes and Contracts. Narr.

[29] Weisflog, W. E. (1987). "Problems of Legal Translation". Swiss Reports presented to the XIIth International Congress of Comparative Law. Schulthess, 179-218.

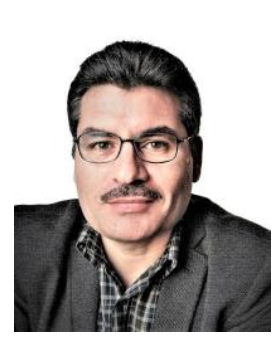

Omar Osman Jabak was born in Syria in 1973. He earned his BA in the English Language Literature from Aleppo University in 1995. He did a postgraduate diploma in literary studies at Aleppo University in 1996. $\mathrm{He}$ did his MA in translation at the University of Salford in the UK. He did his PhD in Translation and Interpretation at Universiti Putra Malaysia in 2018.

$\mathrm{He}$ is currently working at the Department of Foreign Languages, College of Arts and Sciences at University of Nizwa in Oman as Assistant Professor in Translation. His main research interests include translation studies, translation practice, English-Arabic and Arabic-English translation, cultural studies, applied linguistics and EFL. He has translated some English books (fiction and non-fiction) into Arabic. He has also published some books and articles on translation and EFL.

Dr. Jabak is a reviewer for a number of international journals such as International Journal of English and Literature, International Journal of Literature, Language and Linguistics, Asian Research of Arts and Social Sciences, AWEJ for translation \& Literary Studies, Issues in Language Studies, SAGE Open and others. He received three grants from King Saud University for translating two reference books and publishing one research article. 